\title{
Article
}

\section{James Croll and 1876: an exceptional year for a 'singularly modest man'}

\author{
Kevin J. EDWARDS $1,2,3$
}

\author{
${ }^{1}$ Department of Geography and Environment, School of Geosciences, University of Aberdeen, Elphinstone Road, \\ Aberdeen AB24 3UF, UK. \\ ${ }^{2}$ Department of Archaeology, School of Geosciences, University of Aberdeen, Elphinstone Road, Aberdeen AB24 \\ $3 \mathrm{UF}, \mathrm{UK}$. \\ ${ }^{3}$ McDonald Institute for Archaeological Research and Scott Polar Research Institute, University of Cambridge, \\ Cambridge CB2 3ER, UK. \\ Email: kevin.edwards@abdn.ac.uk
}

\begin{abstract}
James Croll left school at the age of 13 years, yet while a janitor in Glasgow he published a landmark paper on astronomically-related climate change, claimed as 'the most important discovery in paleoclimatology', and which brought him to the attention of Charles Darwin, William Thomson and John Tyndall, amongst others. By 1867 he was persuaded to become Secretary and Accountant of the newly established Geological Survey of Scotland in Edinburgh, and a year after the appearance of his keynote volume Climate and time in 1875, he was lauded with an honorary doctorate from Scotland's oldest university, Fellowship of the Royal Society of London and Honorary Membership of the New York Academy of Sciences. Using a range of archival and published sources, this paper explores aspects of his 'journey' and the background to the award of these major accolades. It also discusses why he never became a Fellow of his national academy, the Royal Society of Edinburgh. In the world of 19th-Century science, Croll was not unusual in being both an autodidact and of humble origins, nor was he lacking in support for his endeavours. It is possible that a combination of Croll's modesty and innovative genius fostered advancement, though this did not hinder a willingness to engage in vigorous argument.
\end{abstract}

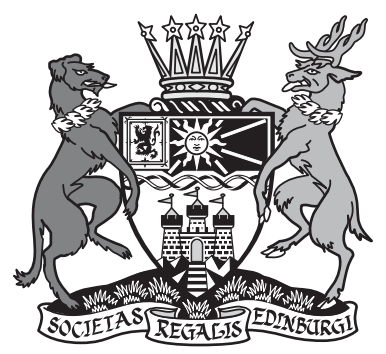

KEY WORDS: honorary degree, learned societies, New York Academy of Sciences, Royal Society of Edinburgh, Royal Society of London, University of St Andrews.

The evening of 2 January 1821 in rural Perthshire, Scotland, was 'a cold wintry night, with the snow lying thickly on the ground'. This inclement weather was the backdrop to the birth of James Croll (1821-1890; Fig. 1) and it was emblematic of an area of research that would come to characterise the scientific work of his life. Croll was an autodidact who left school at the age of 13 years, yet he was to publish a landmark paper in the August 1864 issue of a major scientific journal, the Philosophical Magazine. ${ }^{2}$ His article, 'On the physical cause of the change of climate during geological epochs', ${ }^{3}$ brought his intellectual powers to a national and international audience and was described by obituarists as 'a remarkable paper', ${ }^{4}$ and as the 'paper which laid the foundation of his scientific reputation'.5 Croll's (1875a) tome, Climate and time in their geological relations ${ }^{6}$ was to

\footnotetext{
${ }^{1}$ Croll $(1887$, p. 9).

${ }^{2}$ The London, Edinburgh, and Dublin Philosophical Magazine and Journal of Science: Series 4, published by Taylor \& Francis.

${ }^{3}$ Croll (1864)

${ }^{4}$ Horne $(1892$, p. 172$)$

${ }^{5}$ A. G. (1890, p. 181).

${ }^{6}$ Hereafter termed Climate and time; published with the subtitle, $A$ theory of secular changes of the earth's climate (Croll 1975a).
}

consolidate his ideas and to have a widespread influence upon climate theory. ${ }^{7}$

Croll's astronomically based theory of climate change embodied variations in the Earth's orbit, albedo feedback mechanisms and hemispheric asymmetry. The attendant idea of orbitally forced variations in solar radiation, albeit with chronological inadequacies, and suggested initially by French mathematician Joseph Alphonse Adhémar (1797-1862), presaged the success of Milanokvitch cycles as promulgated by Serbian mathematician Milutin Milanković (1879-1958). ${ }^{8}$ It was James Croll, however, who was to assemble the scientific package and to produce what has been claimed as 'the most important discovery in paleoclimatology'.

Croll corresponded with such luminaries as Charles Lyell, Charles Darwin, Alfred Wallace, John Herschel, William Thomson (Lord Kelvin), Joseph Hooker, John Tyndall and Thomas Huxley (Irons 1896a). Just as Thomas Barclay (1792-1873),

\footnotetext{
${ }^{7}$ Fleming (2006).

${ }^{8}$ Hays et al. (1976).

${ }^{9}$ Bol'Shakov et al. (2012, p. 202).
} 


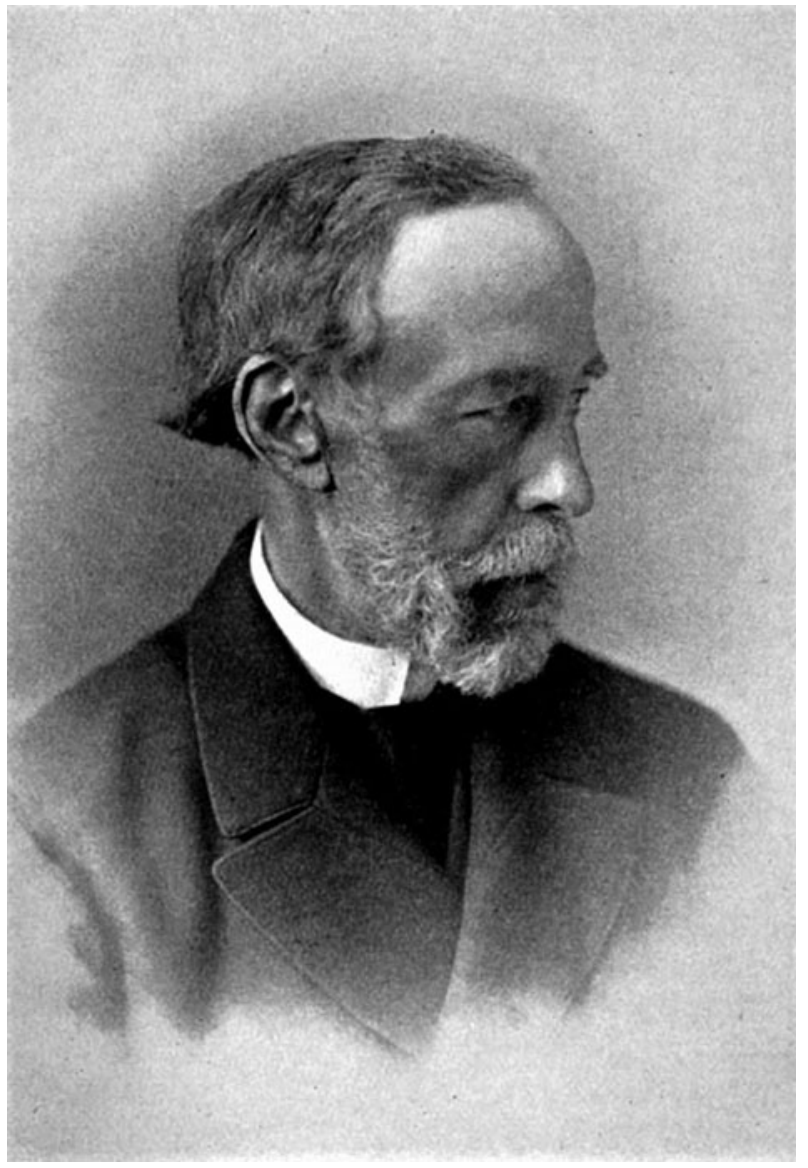

Figure 1 Photograph of James Croll from Irons (1896a, facing p. 405).

Principal of Glasgow University, and James Frederick Ferrier ${ }^{10}$ (1808-1864), Professor of Moral Philosophy at the University of St Andrews, reputedly had a hand in Croll's appointment in 1859 as janitor at Glasgow's Andersonian Institute, ${ }^{11}$ it was seemingly Archibald Geikie (1835-1924), Director of the Geological Survey of Scotland, who plucked Croll from the relative obscurity of a humble position in Glasgow and employed him as Secretary and Accountant of the newly established Survey office in Edinburgh in 1867. By this stage, Croll had not only written more than 20 papers on such topics as electrical currents, heat, gases, glaciology, tidal waves, lunar motion, climate change over geological time and orbital eccentricity, ${ }^{12}$ but he had also produced Philosophy of theism, ${ }^{13}$ a book which reflected his interests and beliefs in spiritual metaphysics.

By 1875, when Climate and time had appeared, Croll had certainly attracted the attention of persons of influence. A year later

\footnotetext{
${ }^{10}$ Ferrier is credited with introducing the word epistemology into English language philosophical writing (Ferrier 1854, p. 46; OED 2014).

${ }^{11}$ Irons (1896a, p. 91). Anderson's (or the Andersonian) Institution was established in 1796 under the will of John Anderson (1726-1796), Professor of Natural Philosophy in the University of Glasgow (University of Strathclyde 2020). Courses included chemistry, natural philosophy, mathematics, medicine and other scientific subjects, together with English, rhetoric, music and art. The institution changed its name to Anderson's University in 1828, but lacking a royal warrant it changed again to Anderson's College in 1877. Dr David Livingstone was a graduate of the Medical School which became an independent institution in 1887, eventually merging with the University of Glasgow Medical Faculty in 1947. Anderson's College merged with other institutions in 1887 to become the main component in the Glasgow and West of Scotland Technical College, which eventually formed the basis of the University of Strathclyde (Royal Charter 1964).

${ }^{12}$ Irons (1896b).

${ }^{13}$ Anon. (1857)
}

he was awarded an honorary doctorate by the University of St Andrews, elected to Fellowship of the Royal Society of London and he became an Honorary Member of the New York Academy of Sciences. Using a range of archival and published sources, this paper explores aspects of the educational journey and background to the award of these major accolades and enquires as to why he never became a Fellow of the Royal Society of Edinburgh, his national academy.

\section{From manual worker to scholar}

Croll's 'Autobiographical sketch' ${ }^{14}$ preceded a 'Memoir' about him, which was assembled by James Campbell Irons, ${ }^{15}$ a solicitor friend to James Croll. Irons' substantial 553-page compilation was published five years after the death of Croll. The relatively brief 33 pages which constitute the 'Autobiographical sketch' had been dictated by Croll to his wife at the behest of friends. In his 'Prefatory note', Croll declared that it was something to which he had 'a strong aversion' and which was produced in this fashion because of 'the pressure of work of a more important character'. ${ }^{16}$

Croll described how, from the age of 11 and from the first number, he had read The Penny Magazine, a serial produced by the Society for the Diffusion of Useful Knowledge and aimed at the working class. ${ }^{17}$ Attracted by the illustrations, this enabled him to acquire an excellent knowledge of the sciences, including mechanics, hydrostatics and electricity, as well as geography, history and biography. By his own admission - though probably a reflection, in part, of his teacher being 'rather harsh and tyrannical $^{18}$ - Croll was an unimpressive pupil and he left school at the age of 13 in order to help in the labours of the family croft.

In the Sketch, Croll recounted how '[t]he bent of my mind at the time was to obtain a university education, which might enable me to follow out physical science. This, however, was a wish that could not be realised, as my father was by far too poor'. ${ }^{19}$ These educational desires were elaborated upon by Irons who recounted that the young James Croll had experienced a 'longing desire for a university education [which] had thus to be stifled, and the project given up as impracticable and unattainable.' It was noted further ${ }^{20}$ that:

The nearest university was St. Andrews, which was about forty miles distant from Wolfhill [near Perth]; and although several bursaries are annually awarded there to clever lads, these were altogether beyond the reach of Croll, who had enjoyed no systematic training in even the elements of mathematics or the Latin or Greek languages.

Instead he undertook an apprenticeship as a millwright in the village of Collace, about $5 \mathrm{~km} \mathrm{E}$ of his birthplace in the parish of Cargill. This apprenticeship as a skilled manual worker foreshadowed one of a more scholarly nature as he pursued informal academic training and intellectual matters. The arduous nature of trade as a millwright led Croll to abandon it at the age of about 22 years and he took himself back to the parish school of St Martins, close to Collace, in order to familiarise himself with algebra before taking up joinery. This occupation, combined with physical ailments (his life was plagued by problems with headaches, heart and an elbow joint), a developing interest

\footnotetext{
${ }^{14}$ Croll (1887).

${ }^{15}$ Irons (1896a).

${ }^{16}$ Irons (1896a, p. 5).

${ }^{17}$ Secord (2000).

${ }^{18}$ Irons (1896a, p. 12).

${ }^{19}$ Irons (1896a, p. 15)

${ }^{20}$ Irons (1896a, pp. 63-64).
} 
in theology, marriage and the need to make a more secure living, encouraged him to try his hand as a tea salesman ${ }^{21}$ in Elgin, a constructor of electrical induction machines for medical purposes, a temperance hotelier in Blairgowrie (where he also spent a year attempting to learn Latin from a local schoolmaster) and an insurance salesman in Scotland and England. The latter was abandoned when his wife became ill and had to be nursed by her sisters in Glasgow. Insurance had been 'about the most disagreeable part of my life. To one like me, naturally so fond of retirement and even of solitude, it was painful to be constantly obliged to make up to strangers'. ${ }^{22}$

Croll turned his hand to writing and produced, at the age of 36 and anonymously, Philosophy of theism. ${ }^{23}$ 'The direct object of the work is not to prove the existence of God, but to investigate the method to be pursued, in order to arrive at a proof of his existence'. ${ }^{24}$ Three distinguished readers of the volume, to whom Croll had sent copies, were complimentary. Thomas Barclay, Principal of Glasgow University and a fighter for religious liberalism, was succinct in his praise ('[i]t furnishes very satisfactory evidence that you have thought deeply on what must be admitted to be a deep subject'), but tellingly went on to 'very much sympathise with you in your desire to have the benefit of a university education, and if my influence can avail in obtaining a bursary for you, it shall be most willingly used' (letter dated 6 May 1858). ${ }^{25}$ John Cairns ${ }^{26}$ (1818-1892) exclaimed,

I am much pleased with the advanced state of intelligence displayed by the writer as to the exact shape and pressure of metaphysical questions at the present time. He has evidently read in many schools; and, what is still better, he is a vigorous and independent thinker. (Letter dated 12 August 1858) ${ }^{27}$

Cairns was not uncritical, however, and he hoped that the writer 'will produce something still better, and needs only to give himself entirely to this topic or any other to secure distinguished success.' James Frederick Ferrier at the University of St Andrews was 'impressed with the acuteness and power of coherent and independent thought which it displays' (letter dated 15 January 1859). ${ }^{28}$

In 1859, whether at the urging or influence of Thomas Barclay and James Ferrier, ${ }^{29}$ or Mr Walter Crum (chairman of the Andersonian and father-in-law of William Thomson) as mentioned by his friend and obituarist John Horne (1848-1928), ${ }^{30}$ Croll became janitor at Anderson's College and Museum. This enabled access to an extensive scientific library and was not taxing mentally, while his brother David (1822-1876), afflicted by kyphosis $^{31}$ and who had lived with Croll and his wife since the

\footnotetext{
${ }^{21}$ A trade to which he was introduced by David Croll, a Perth grocer, and the father of his biographer, James Campbell Irons.

${ }^{22}$ Irons (1896a, p. 29); Edwards \& Robinson (2021).

${ }^{23}$ Anon. (1857).

${ }^{24}$ Irons (1896a, p. 85); Finnegan (2011).

${ }^{25}$ Irons (1896a, p. 90)

${ }^{26}$ For three years a shepherd in Berwickshire (like his father before him), John Cairns had entered Edinburgh University in 1834, graduating top of the class in classics, philosophy and mathematics, and rising to become Principal of the United Presbyterian Theological College having previously declined the invitation to become the Principal of Edinburgh University (Bayne 1901). He was a critic of Ferrier's metaphysics; indeed, he was instrumental in preventing Ferrier from obtaining Chairs in Philosophy and Logic and Metaphysics at the University of Edinburgh (Keefe 2015).

${ }^{27}$ Irons (1896a, p. 88)

${ }^{28}$ Irons $(1896$ a, p. 87$)$

${ }^{29}$ Irons (1896a, p. 91).

${ }^{30}$ Horne $(1892$, p. 171).

${ }^{31}[\mathrm{H}] \mathrm{e}$ was deformed, being hunchbacked, in consequence, as it was supposed, of a fall received when an infant' (Croll 1887, p. 30).
}

death of Croll's mother in 1858, was able to do most of the routine duties of the post. ${ }^{32}$ It was perhaps no surprise, as Croll recounted in the Sketch, that 'Taking it all in all, I have never been in any place so congenial to me as that institution proved' ${ }^{33}$

The scientific knowledge he had gained from The Penny Magazine, and subsequent reading prior to and during his janitorship at the Andersonian, led initially to his first publication in the modern scientific sense. ${ }^{34}$ This concerned the experiment of André-Marie Ampère (1775-1836) on electrical repulsion and was followed by related papers ${ }^{35}$ and others on such topics as chemistry and heat, tidal waves, the Earth's rotation and lunar motion. 36

The year 1864 alone saw the appearance of five papers, all in the Philosophical Magazine. His innovative contribution on climate change ${ }^{37}$ was received in a less than laudatory fashion in hindsight at least - by William Thomson: ${ }^{38}$

[his paper] deservedly gained the careful consideration both of geologists and of astronomers. This speculation undoubtedly presented a vera causa for some of the changes of climate which have occurred in geological history, although we can scarcely consider it adequate to be so powerful and exclusive a factor as Croll endeavoured to make it.

Notwithstanding the passive disparagement of the future Lord Kelvin, it might be said that his consideration of Croll failed to adequately convey the impact that the 1864 paper and others, leading up to the publication of the summative and magisterial Climate and time in 1875, had had upon the world of science. This has been rehearsed in both learned and more popular outlets. $^{39}$

In short, cognisant of previous work by Joseph Adhémar, John Herschel, Alexander von Humboldt and Urbain Le Verrier, and aware of the arguments for glaciation by Louis Agassiz, Charles Lyell and Archibald Geikie, Croll had developed a comprehensive astronomical theory of climate change, which depended upon the changing shape of the Earth's orbit (eccentricity, a 96,000 -year cycle), the resultant tilting to or away from the sun (precession of the equinoxes, with a periodicity of 21,000 years) and the wobble or axial tilt of the Earth (obliquity of the ecliptic on a 41,000 -year cycle). As pointed out by Sugden, ${ }^{40}$ this last component was recognised by Croll - it had not been Milankovitch who had made the connection, as popularly expressed by Bryson. ${ }^{41}$ Croll devised a retrospective and prospective chronology from Le Verrier's formulae. Significantly, Croll posited the involvement of two positive feedback mechanisms. Firstly, there was albedo, whereby lowered insolation would cumulatively increase snow or ice cover, which would reflect heat back into space as well as to accentuate cloud and fog cover. Secondly, he maintained (in the face of a bitter correspondence with William Carpenter ${ }^{42}$ ) that ocean currents were driven

\footnotetext{
${ }^{32}$ Irons (1896a, pp. 92, 96).

${ }^{33}$ Irons (1896a, p. 30).

${ }^{34}$ Croll (1861).

${ }^{35}$ Croll (1862a, b)

${ }^{36}$ See Irons (1896b) for a publications list.

${ }^{37}$ Croll (1864).

${ }^{38}$ Thomson (1891, p. 220).

${ }^{39}$ E.g., Imbrie \& Imbrie (1979); Tasch (1986); Farrow (2001); Gribbin \& Gribbin (2001); Fleming (2006); Finnegan (2011); Bol'shakov et al. (2012); Sugden (2014); Thompson (2015); Dry (2019); Robinson (2020). ${ }^{40}$ Sugden $(2014$, p. 606).

${ }^{41}$ Bryson (2004, p. 512).

${ }^{42}$ William Benjamin Carpenter (1813-1885) was a physiologist and marine zoologist, and was Professor of Physiology at the Royal Institution and subsequently Registrar of University College London (Smith 2006).
} 
mainly by winds rather than by differences in water density, and climate differences between pole and equator would be powerful drivers of warm-cold water configurations. ${ }^{43}$

Croll's writings, on the whole, were embraced avidly by men of science of such stature as Charles Darwin, Thomas Huxley and William Thomson. ${ }^{44}$ The appearance of the monumental Climate and time in 1875 was the forerunner to a year of honours.

\section{University of St Andrews - towards the degree of LL.D.}

Acknowledgement of the young James Croll's desire for a university education has already been cited. In a letter written 26 May 1865, the year following Croll's 'remarkable paper' in the Philosophical Magazine, Andrew Crombie Ramsay (1814-1891) of the Geological Survey ${ }^{45}$ and President of the Geological Society of London wrote to James David Forbes (1809-1868), physicist, glaciologist and Principal of the United College, University of St Andrews (Fig. 2):

I fancy that $\mathrm{Mr}$ Croll of Glasgow is at present engaged on a memoir on changes of climate in geological periods. I have a very high opinion of him, he is a singularly modest man, and I suspect is almost quite self-educated. ${ }^{46}$

It is unknown whether Forbes took any great interest in Croll or his climate-glacial ideas. The two men were linked, however, with regard to their observations on electricity, when $\mathrm{Croll}^{47}$ (1861) proposed that an experiment in support of a theory of electrical current advanced by Ampère could be explained otherwise, partly in accommodating a theory put forward by Forbes. ${ }^{48}$

Recognition for Croll was to come from Principal Forbes's institution some half dozen years after his death. Matthew Forster Heddle (1828-1897), a physician turned mineralogist, Professor of Chemistry at the University of St Andrews (and keen mountaineer), ${ }^{49}$ wrote to Croll: $:{ }^{50}$

\section{ST. LEONARDS, ST. ANDREWS,}

23 December 1875.

MY DEAR SIR, - I have to acknowledge receipt of many of your deeply interesting and powerfully reasoned papers.

I have for some past years considered your work so deserving of public recognition that two years ago I recommended you to our Faculty of Arts for promotion to the degree of LL.D. in our University. Your claims were even then admitted, but I was requested to defer my motion on the grounds of your juvenility. I again this year brought you forward, and our faculty has unanimously and cordially agreed to recommend you to the Senate for that degree, so that the matter may be considered as settled, unless you yourself decline. I have to mention that there is, however, a diploma fee of $£ 10,10$ s., which I fear we cannot remit. For myself, I have had more than usual

\footnotetext{
${ }^{43}$ Croll (1867a, b); and see F. R. S. (1874). This has been viewed as 'a slightly irrational, noisy, dispute that is typical of sciences with insufficient data' (Wunsch \& Ferrari 2018, p. 7.7).

${ }^{44}$ Irons (1896a); Kushner (2004); Fleming (2006).

${ }^{45}$ Also Professor of Geology at the Royal School of Mines (subsequently absorbed by Imperial College London).

${ }^{46}$ University of St Andrews, University Library Special Collections, Papers of James David Forbes: msdep7/Incoming Letters 1865/46 (a,b). A transcription of the full text of the letter is contained in supplementary material 1.

${ }^{47}$ Croll (1861).

${ }^{48}$ Forbes (1861)

${ }^{49}$ Johnston (2015).

${ }^{50}$ Irons (1896a, pp. 288-89).
}

freedom in bringing you forward, seeing that I, unfortunately for myself, have not the pleasure of your personal acquaintance, and that I do not quite agree with you in all your views, which perhaps enables me all the more to admire the originality of your mind, the courage of your argument, and your independence of scientific redtapeism. - Truly yours,

Croll replied immediately: ${ }^{51}$

\section{W. FORSTER HEDDLE.}

24th December 1875.

The announcement that your University proposed to confer on me an honour the highest to which any scientific man can aspire, certainly takes me by surprise. I hope you will not deem it affectation when I say that I do not consider that I have done anything deserving of such an honour, and that I must look upon it more as a reward to a self-taught man for a long and persevering struggle against difficulties, than for any positive results which he has as yet been able to achieve.

Allow me to offer to you personally my warmest thanks for the kindly interest you have taken in this matter.

No mention of Heddle's attempt to obtain the honorary degree for Croll in 1873 seems to be evident in the surviving archival records for the University. The first indication of the award for Croll is that appearing in the minutes of the Senatus Academicus for 8 January 1876 (Fig. 3) ${ }^{52}$ (after Heddle had already written to Croll):

Dr Swan ${ }^{53}$ as Dean of the Faculty of Arts reported that the Faculty of Arts unanimously recommend to the Senatus that the degree of Doctor of Laws be conferred on the following gentlemen:

Professor James Stuart, M.A. Cambridge.

William Wallace, M.A. Oxford.

James Croll, H.M. Geological Survey, Scotland.

William D. Bruce, Schoolmaster, Alloa.

This was confirmed by the Senatus on 12 February $1876 .{ }^{54}$

Croll's fellow graduands were all products of St Andrews. James Stuart (1843-1913) had graduated in 1861 and subsequently became Third Wrangler ${ }^{55}$ at Trinity College, Cambridge, in 1866, before becoming a Fellow of Trinity (1867) and Professor of Mechanism and Applied Mechanics (1875). ${ }^{56}$ William Wallace (1844-1897) graduated from St Andrews by 1864, when he enrolled at Balliol College, Oxford, graduating in classics in 1868 and becoming a fellow of Merton College and its

\footnotetext{
${ }^{51}$ Irons (1896a, p. 289)

${ }^{52}$ University of St Andrews, University Library Special Collections, Minutes of Senatus, UYUY452/19, p. 383.

${ }^{53}$ William Swan (1818-1894), Professor of Natural Philosophy (Physics) at the University of St Andrews from 1859, having been passed over for the equivalent chair at Marischal College (Aberdeen University) in favour of James Clerk Maxwell (Reid 2008).

${ }^{54}$ University of St Andrews, University Library Special Collections, Minutes of Senatus, UYUY452/19, p. 389.

${ }^{55}$ Third place within the first class honours category of the final undergraduate examinations in mathematics at the University.

${ }^{56}$ STRT 862J (2020). He was later to become Rector of St Andrews and an MP for the Liberal Party. As the magazine Vanity Fair satirised (5 October 1899): 'He neither shoots nor fishes... but he yachts, he cycles, he plays golf, and he sketches.... He champions Women's Suffrage because, being a student of Exact Science, he cannot understand Woman... he is a wicked Radical, whom the Water Companies hate, although he has friends among the Tories. He is a most tireless person of extraordinary physique, who can go all day without food; and though he can dine, he generally eats. Although he is a Professor he is neither a prude nor a pedant; and if it were not for his pernicious Politics he would be a good fellow.'
} 
JAMES ROLL AND THE YEAR 1876

195

Closer.

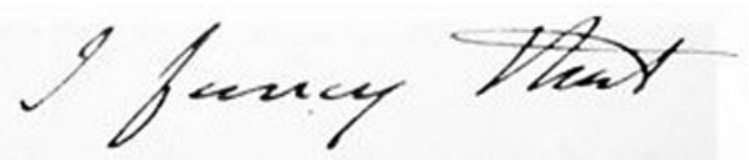

line Gerald

olererpon

is at precut cyeypd in

- Memoir on Cleanup

fusion. I have very

high opicisin of tecien.

He is a Singularly sublet

mon, $d 9$ suspect is alseosh

quite ref-esnowtal.

Figure 2 Portions of letter dated 26 May 1865 to James David Forbes from Andrew Crombie Ramsay concerning James Croll. For transcription of the full text, see supplementary material 1 available at https://doi.org/10.1017/S1755691021000074. Published by permission of University of St Andrews, University Library Special Collections, Papers of James David Forbes: msdep7/Incoming Letters 1865/46 (abb).

https://doi.org/10.1017/S1755691021000074 Published online by Cambridge University Press 


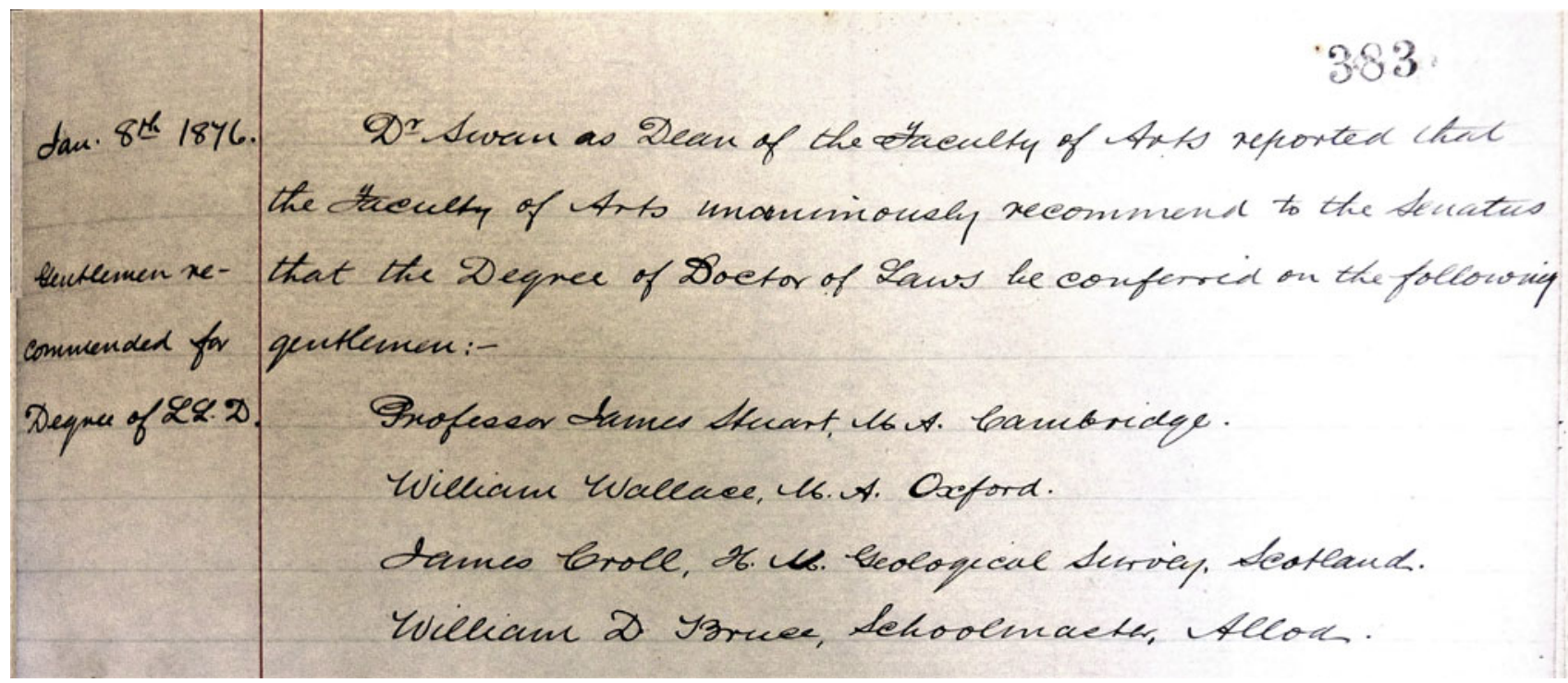

Figure 3 From the minutes of the Senatus Academicus for the University of St Andrews for 8 January 1876 showing agreement to confer the degree of LL.D. upon James Croll. Published by permission of University of St Andrews, University Library Special Collections.

librarian. ${ }^{57}$ Information on William D. Bruce is sparse. The report on the LL.D. graduation published in The St Andrews Citizen stated: 'D. [sic.] Bruce, Esq., a distinguished alumnus of the University, late President of the Educational Institute of Scotland, Headmaster of the Public School, Alloa, and author of several educational works.'

The young ages of James Stuart (33 years) and William Wallace (32 years) were presumably apparent to Heddle (and Croll) who had been rebuffed in 1873 over Croll's candidature for an honorary degree owing to Croll's 'juvenility', when the latter was then 52 years of age. It might also be noted that Archibald Geikie, Croll's boss at the Geological Survey and conjointly Murchison Professor of Geology and Mineralogy at the University of Edinburgh, received an LL.D. from St Andrews in 1872 when 37 years old (having been proposed by Heddle). ${ }^{58}$ It might be wondered if this was Croll caught up in notions of professionalisation within the scientific community ${ }^{59}$ or simply haughtiness on the part of the University, given that Croll was not a graduate of St Andrews or any university and he was in relatively humble employment. Geikie never finished his undergraduate training at Edinburgh, although he had clearly become a person of standing ${ }^{60}$ - but then geology was a rather unusual occupation with an aversion to the monopolism of other learned professions. ${ }^{61}$

Heddle's notification of a diploma fee of $£ 1010 \mathrm{~s}$. (ten guineas) required of the recipient for the award of an honorary degree would likely seem bewildering to modern readers. This was a large sum of money in 1876, and in today's terms could have been the equivalent of between $£ 657$ and $£ 1000$, depending on the measure of wealth. ${ }^{62}$ Considering that Croll's annual salary

\footnotetext{
${ }^{57}$ den Otter (2012). He was to become White's Professor of Moral Philosophy at Oxford in 1882 and he delivered the Gifford Lectures for 1893-1894 (Wallace 1898; McGilvary 1900). Of a 'brusque and sarcastic' manner, he was also described as a man of 'much genuine nobleness and a staunch uprightness of thought and speech [whose] acquaintances were numerous and friendly, but his intimates few and attached' (The Times 20 February 1897). He died following a bicycle accident

${ }^{58}$ Johnston (2015).

${ }^{59}$ Cf. Barton (2003)

${ }^{60}$ Oldroyd (2004)

${ }^{61}$ Porter (1978); Secord (1986).

${ }^{62}$ https://www.nationalarchives.gov.uk/currency-converter; https://www. measuringworth.com/
}

was in the order of $£ 350$ p.a. when he retired in $1880,{ }^{63}$ this fee was not insignificant. The decision to accept it without demur (at least in terms of the written record) perhaps reflects Croll's desire for academic recognition and a distaste for rejecting the honour offered to him.

As was reflected in his letter to Croll dated 23 December 1875 , the existence of such a fee was a subject of irritation and embarrassment on the part of Heddle and some of his fellow professors at St Andrews. In 1873, the Senatus minutes recorded that 'Professor Swan gave notice that at next meeting he would move that the fee for Honorary degrees be abolished', only for it to be followed a week later by 'Professor Swan's motion that the fees for Honorary degrees be abolished was withdrawn. ${ }^{64}$ This may have been because of an agreement that a potential way forward was about to transpire: ${ }^{65}$

Professor Campbell ${ }^{66}$ moved for a small committee to enquire into the practice of this University, with regard to the exaction of fees for Honorary degrees from Professors of Scottish Universities, and to consider how far it may be advisable to conform the practice of this University to that of others. The motion was agreed to - the Committee to consist of Drs Mitchell and Heddle and Professor Campbell - Convenor.

Lewis Campbell reported on behalf of the Committee less than a month later: ${ }^{67}$

Your Committee have ascertained that the custom of the other Universities is as follows, viz:

1. In Edinburgh and Aberdeen no fee is exacted for the Honorary Degree of LL.D.

2. In the University of Glasgow a fee of $£ 20$ is exacted, which is reduced to $£ 17$ in the case of M.A.s of Glasgow.

\footnotetext{
${ }^{63}$ Irons (1896a, pp. 40, 537).

${ }^{64}$ University of St Andrews, University Library Special Collections, Minutes of Senatus, UYUY452/19, pp. 210, 213.

${ }^{65}$ University of St Andrews, University Library Special Collections, Minutes of Senatus, UYUY452/19, p. 277, for 8 March 1873.

${ }^{66}$ Lewis Campbell (1830-1908), Professor of Greek. Friend and biographer of James Clerk Maxwell (Campbell \& Garnett 1882) and of Benjamin Jowett (Abbott \& Campbell 1897). Described as sensitive, nervous and excitable, with a mildly bohemian lifestyle (Craik 2004).

${ }^{67}$ University of St Andrews, University Library Special Collections, Minutes of Senatus, UYUY452/19, pp. 232-33, for 12 April 1873.
} 
This fee is however invariably remitted when the Graduate is a Professor of any Scotch University, as well as in certain other cases, which are less exactly defined.

It thus appears that this University is singular in exacting the fee from Scotch Professors and your Committee therefore recommend that the example of Glasgow should be followed in remitting such fee to them.

The report was approved and patently ignored the generosity of Aberdeen and Edinburgh Universities towards professorial honorary graduands and it had nothing to say about the ability to pay of those being honoured. That there was flexibility within the system when it suited was demonstrated in the following year. The Senatus minutes for 14 February $1874^{68}$ reported that agreement was reached in conferring the degree of LL.D. on 'William D. Whitney, Esq. Professor of Sanscrit [sic.], Yale College, America', but '[i]t was resolved that in the case of Mr Whitney ${ }^{69}$ the usual fee should not be exacted.' Was this act of benevolence because Whitney was a professor, would have travel costs from the USA or because to do otherwise would look miserly beyond Scotland, a country for which a stereotype of meanness had a long history? ${ }^{70}$ Whatever the facts of the situation, Croll had little choice but to accede to the payment of a fee if he was to become an honorary doctor of Scotland's oldest university.

\section{Croll and the Royal Society of London}

Having written to John Tyndall (1820-1893), Professor of Physics at the Royal Institution and a Fellow of the Royal Society of London (FRS), Croll received the following reply: ${ }^{71}$

9 November 1868.

MY DEAR SIR, - If I had a separate copy of that article, I would gladly send it to you. I will write a note to the sub-editor and ask him to send you the date.

It gave me pleasure to hear Mr. Darwin express the delight he experienced in reading one of your recent papers. I had been staying with him for a day or two. He is, for him, exceedingly well. - Yours very truly,

\section{JOHN TYNDALL.}

I am glad the notice in the Proceedings pleased you. Are you a Fellow of the Royal Society?

There seems to be no record of Croll's response, and it is uncertain whether Tyndall assumed that Croll might be an FRS at this date or, supportively and implicitly, was offering to nominate him should it not be the case. In September 1875, however, Croll wrote $^{72}$ to George Carey Foster (1835-1919) whom he met for the first time at the Andersonian where Foster was Professor of Natural Philosophy from 1862 to $1865 .{ }^{73}$ Foster was now Professor of Physics at University College London ${ }^{74}$ :

\footnotetext{
${ }^{68}$ University of St Andrews, University Library Special Collections, Minutes of Senatus, UYUY452/19, pp. 265-66.

${ }^{69}$ William Dwight Whitney (1827-1894); first president of the American Philological Association and editor-in-chief of The Century Dictionary (Briggs 2020). There is another tangential link with Croll. Whitney's artist and suffragist daughter-in-law, Anna Josepha Newcomb (1871-1957), was the child of astronomer Simon Newcomb who tangled with Croll during the 'Croll-Newcomb controversy' (see section 4).

${ }^{70} C f$. Piskorska (2016).

${ }^{71}$ Irons (1896a, p. 203).

${ }^{72}$ Irons (1896a, p. 283).

${ }^{73}$ Fison (1919).

${ }^{74}$ 'No one ever proved to be a reader more interested or a friend more faithful' (Irons 1896a, p. 259). Foster was later to become Principal of UCL. 'A man of extreme modesty and of high if not commanding ability, Carey Foster had made few direct contributions to scientific literature; but the soundness of his judgment, his almost passionate love of exact knowledge, and his enthusiasm, earned the respect of all, and made his presence invaluable on the many committees of learned societies, the
}

EDINBURGH, 15th September 1875. Professor Foster, F.R.S.

MY DEAR SIR, - I send you a copy of my paper read before the British Association. I should like exceedingly well to have your opinion as to the correctness of my result. ${ }^{75}$ Of course I shall make no public use of what you may say, it is simply for my own satisfaction....

I intend applying for admission into the Royal Society. If you can see your way clear to give me a little aid, it will be esteemed a very special favour. Apologising for troubling you so often, I am, yours most truly,

\section{JAMES CROLL.}

Foster's response, dated 1 October 1875, included an encouraging ending: 'I shall be greatly pleased to support your candidature at the Royal Society in any way in my power' ${ }^{76}$ If Foster did help Croll's admission, this is not directly apparent and he had no official role within the Society at this time. ${ }^{77}$ Croll's certificate of candidature (Fig. 4) was submitted on 2 December 1875, read to the Society on 27 January 1876 and he was elected 1 June 1876, one of 15 Ordinary Fellows for the year of a total number nominated of between 50 (in 1862) and 80 (in 1900). ${ }^{78}$ His proposers included a stellar group of the scientific establishment of whom, for instance, Charles Darwin and John Tyndall signed 'from general knowledge' and Andrew Ramsay, Archibald Geikie and William Thomson signed 'from personal knowledge', in addition to others perhaps less well known, but distinguished nevertheless. The whole process may have been driven by Ramsay as reflected in his signature at the top of the personal knowledge column. Darwin is known to have signed Croll's certificate with 'real pleasure' ${ }^{79}$ Perusal of his nominators reveals their establishment and academic credentials (Table 1). Thus, and not exclusively, no less than six of his 17 supporters were, or were to become, knights or peers of the realm; 11 were graduates (all from ancient universities of the time and only one from the newer institution of London); and, at various instants, ten were professors, five Directoror Surveyor-generals, four keepers of national museums and two politicians. Ten worked as geologists at some stage, five as medical professionals (with one, James Hector, who was both a geologist and a surgeon) and two archaeologists. Apart from often senior roles within the Royal Society of London, many of Croll's proposers were also Fellows of the Geological Society of London (12) and the Royal Society of Edinburgh (7). There was a distinct lack of lawyers or clergymen (in 1860, only slightly more than half the Fellows were scientists; Lyons 1939) - though many and perhaps most of the supporters, along with Croll himself, were strong Christian believers and this, of course, was a period of enormous religious interest and debate. ${ }^{80}$

There were clearly some strong social, disciplinary and geographical connections between Croll's proposers for the Fellowship, if not with Croll himself (Table 1). Darwin's correspondents included his friends John Lubbock (who lived in the same Kent village of Downe) and William Sharpey, as well as John Tyndall,

British Association, and the various university boards of which he became a member' (Fison 1919, pp. 412-13). 'The language of exaggeration was always repulsive to him.... To the writer during his early struggles in London he held out a helping hand...he was one of the best and most unselfish of men' (O. J. L. 1920, pp. xvii-xviii).

${ }^{75}$ This was in connection with his academic altercations with William Carpenter.

${ }^{76}$ Irons (1896a, p. 283).

${ }^{77}$ Royal Society Collections EC/1869/09. Foster's own certificate was signed by Tyndall and Lubbock - signatories to Croll's certificate - in addition to Charles Lyell and David Forbes; Foster was clearly well connected to men of science.

${ }^{78}$ Lyons (1938).

${ }^{79}$ Burkhardt \& Smith (1994, p. 440)

${ }^{80}$ Turner (1978); Finnegan (2011). 
being desirous of admission into the ROYAL SOCIETY OF LONDON, we, the undersigned, propose and recommend him as deserving that honour, and as likely to become a useful and valuable Member. Dated this 2. day of december 18\%5-

From General Knowledge.

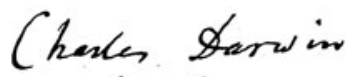

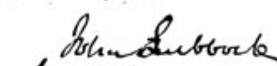

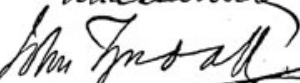

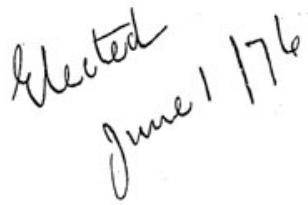

nome.

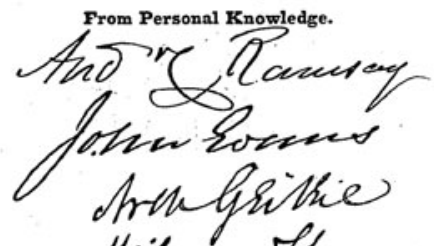
Hilliam thomson Pigrant Alen Thomson Qrout Sthiciags

nend to the Society on the $27^{\text {th }}$ day of anuenry 1876

Figure 4 Certificate of candidature for James Croll, courtesy of the Royal Society of London (Collections EC/1876/08).

Andrew Ramsay, Archibald Geikie and James Croll. ${ }^{81}$ Geikie was Ramsay's friend and biographer ${ }^{82}$ and had enticed Croll from his janitorial position at the Andersonian to work in the Geological Survey of Scotland (patronage was seemingly a strong component of Scottish geological life ${ }^{83}$ ). Allen Thomson and William Sharpey

\footnotetext{
${ }^{81}$ Darwin (2020)

${ }^{82}$ Geikie (1895).

${ }^{83}$ Porter (1978, p. 826) tellingly outlines the nepotistic linkages between Roderick Impey Murchison, Andrew Ramsay, Archibald and James Geikie, and Edwards Hull. Such advantage apparently distressed James
}

co-taught on medical lecture courses in Edinburgh ${ }^{84}$ and no less than five proposers were or went on to become Presidents of the Geological Society of London (Ramsay, Evans, Etheridge, Woodward and twice in the case of Geikie). ${ }^{85}$ While all seven of those

Geikie (Newbigin \& Flett 1917). Given that Hull was '[a] hard-working man of shallow intellect' (Herries Davies 2004), it may have been a godsend that his entry to the Geological Survey was assisted by Murchison 'as my family was connected with his by marriage' (Hull 1910, p. 9). ${ }^{84}$ Sykes (2004).

${ }^{85}$ Geological Society (2020). 


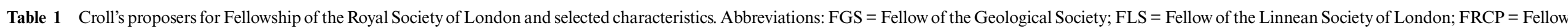

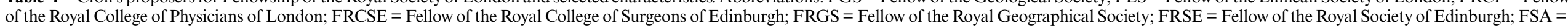
Fellow of the Society of Antiquaries of London; FZS = Fellow of the Zoological Society of London; OM = Order of Merit; PC = Privy Counsellor.

\begin{tabular}{|c|c|c|c|c|c|}
\hline Name & Occupation & University training & Honours & Other societies included & Nationality \\
\hline \multicolumn{6}{|l|}{ From general knowledge } \\
\hline Charles R. Darwin & Naturalist, geologist & $\begin{array}{l}\text { Edinburgh (no degree) } \\
\text { Cambridge }\end{array}$ & & $\begin{array}{l}\text { FRGS, FLS, FZS, FGS, } \\
\text { Hon FRSE }\end{array}$ & English \\
\hline John Lubbock & Banker, politician, archaeologist & & $\begin{array}{l}\text { Knight, Baron, } \\
\text { PC }\end{array}$ & FGS, FLS, FSA & \\
\hline John Tyndall & Physicist, professor (Royal Institution) & Marburg & & FGS & Irish \\
\hline H. Charlton Bastian & Physiologist, professor (UCL) & London & & FRCP & English \\
\hline $\begin{array}{l}\text { M. H. Nevil } \\
\text { Story-Maskelyne }\end{array}$ & Geologist, professor (Oxford), Keeper British Museum, politician, pioneer photographer & Oxford & & FGS & English \\
\hline Henry B. Woodward & Geologist, Keeper British Museum & & & FGS & English \\
\hline Andrew Scott Waugh & Army officer, Surveyor-general of India & & & FRGS & $\begin{array}{l}\text { Scottish/born } \\
\text { India. }\end{array}$ \\
\hline \multicolumn{6}{|l|}{ From personal knowledge } \\
\hline Andrew C. Ramsay & Geologist, professor (UCL), Director-general of the Geological Survey & & Knight & FGS & Scottish \\
\hline John Evans & Archaeologist, geologist & & Knight & FGS, FSA & English \\
\hline Archibald Geikie & $\begin{array}{l}\text { Geologist, professor (Edinburgh), Director-general of the Geological Survey of Great } \\
\text { Britain }\end{array}$ & Edinburgh (no degree) & Knight, OM & FGS, FRSE & Scottish \\
\hline William Thomson & Physicist, professor (Glasgow), mathematician, engineer & Glasgow, Cambridge & Baron, OM, PC & FRSE & Irish \\
\hline Robert Grant & Astronomer, professor (Glasgow) & Aberdeen (no degree ${ }^{1}$ ), Paris & & & Scottish \\
\hline Allen Thomson & Physician, professor (Aberdeen, Edinburgh, Glasgow) & Edinburgh, Paris & & FRSE, FRCSE & Scottish \\
\hline Robert Etheridge & Geologist, palaeontologist with Geological Survey and British Museum & & & FRSE, FGS & English \\
\hline William Sharpey & Anatomist, physiologist, professor (UCL) & Edinburgh & & FRSE, FRCSE, FGS & Scottish \\
\hline James Hector & Geologist, surgeon, Director of the Geological Survey and Museum of New Zealand & Edinburgh & Knight & FRSE, FGS, FRGS, FZS & Scottish \\
\hline Edward Hull & $\begin{array}{l}\text { Geologist, Director-general of the Geological Survey of Ireland, professor (Royal College } \\
\text { of Science for Ireland) }\end{array}$ & Dublin & & FGS & Irish \\
\hline
\end{tabular}

${ }^{1}$ Although he had an MA, this was honorary rather than the normal undergraduate degree from one of the ancient Scottish universities (Clerke 2010). 
nominating him 'from general knowledge' were English, those signing 'from personal knowledge' were a slightly more eclectic mix (six Scottish, two Irish and two English). The fact that most of the supporters from general knowledge were based in the $\mathrm{S}$ of the country may reflect Croll's aversion to travel far or to socialise (see below), quite apart from financial impediments. Eight sponsors were geologists, but only one (Robert Grant) was an astronomer. Data for 1860 , for which disciplinary information has been collated, ${ }^{86}$ show that of the 330 scientific Fellows of the Society (of a total of 630 ), $10.1 \%$ were geologists, $6.6 \%$ astronomers and the largest grouping consisted of physicians and surgeons at $35.6 \%$.

The papers chosen for the certificate were prefaced with the statement that Croll was '[a]uthor of many original and valuable contributions to Geology \& Physical Geography, of which the following may be named' and which then proceeded to list:

On the Physical cause of changes of Climate during Geological epochs. Phil Mag Augt 1864

The Excentricity of the Earth's Orbit. Phil Mag Jany 1866, Feby 1867

Geological Time and date of Glacial and Miocene

Periods Id May Augt Nov 1868

The Physical Cause of the Motion of Glaciers Id March 1869 Sept 1870

The Supposed greater Loss of Heat by the Southern Hemisphere. Id Sept 1869

Ocean Currents. Id Feby March Octr 1870; Oct 1871;

Feby 1874 March June 1874

Change of Obliquity of Ecliptic: its effect on Climate. Id

June, August 1867

Physical Cause of Submergence during Glacial Epoch.

Id April 1866. Geol Mag July Augt 1874

Boulder Clay of Caithness \& Glaciation of North Sea.

Geol Mag May June 1870

Method of determining mean thickness of Sedimentary

Rocks. Geol Mag March 1871

What determines Molecular Motion? - the Fundamen-

tal Problem of Nature Phil Mag July 1872

Climate and Time in their Geological Relations. 8vo,

London 1875

Given the focus on geology and physical geography, and the disciplines from which most of Croll's proposers came, it is hardly surprising that his papers on electricity were not mentioned, while his Philosophy of theism would be viewed as irrelevant to the nomination process. As well as being then recent, Climate and time $^{87}$ is perhaps to be seen as the final crowning item. The 11 papers mentioned represented only a small proportion $(17.5 \%)$ of the 63 items constituting his scientific oeuvre to the end of 1875 .

Although elected formally 1 June 1876 by the Fellowship as a whole, his name had already been ratified by the Council of the Society, and Croll's successful nomination had been communicated to him by Frederick John Owen Evans (1815-1885), ${ }^{88}$ Hydrographer of the Royal Navy: ${ }^{89}$

HYDROGRAPHIC DEPARTMENT, ADMIRALTY, 11th April 1876.

James Croll, Esq.

MY DEAR SIR, - I have just left a Council meeting of the Royal Society, and am exceedingly pleased to acquaint

\footnotetext{
${ }^{86}$ Lyons (1939).

${ }^{87}$ Croll (1875a)

${ }^{88} \mathrm{~A}$ 'zealous contributor to magnetic science', especially when the naval switch from wood to iron threatened to make 'the time-honoured compass... a useless toy' (Anon. 1886, p. 184; Harrison 1885-1900).

${ }^{89}$ Irons (1896a, p. 309).
}

you of your selection as one of the fifteen candidates for election by the general body. Accept my best wishes on the occasion. - Yours faithfully,

F. EVANS.

Having endured the possible shock of a ten-guinea fee in order to secure his Doctor of Laws from St Andrews, he presumably knew that this was to be repeated at some level for Fellowship of the Royal Society. When Croll was elected FRS in 1876 the admission fee was $£ 10$, with an annual subscription of $£ 4 .{ }^{90}$ There is no indication that Croll was exempted, ${ }^{91}$ and it may be imagined that these fees were not seen as inconsequential. ${ }^{92}$ It might be noted, however, that in 1881, the year after his retirement from the Geological Survey, the census revealed that he and his wife Isabella employed a servant (Mary Wilson) at their Edinburgh home, 21 St Catherine's Place, Newington. Given the financial difficulties that are reflected in Croll's efforts to secure a pension and a grant from the Royal Literary Fund, ${ }^{93}$ this is perhaps perplexing - but he was to write, 'I had no alternative but to give up housekeeping and go into cheap lodgings'. ${ }^{94}$ He certainly valued both the honorary doctorate and the Fellowship of the Royal Society greatly and he habitually used the post-nominals for both in his publications, although this was standard practice for the time and for long afterwards. They were also handwritten into the title page of a signed copy of Climate and time, as well as appearing, at his instruction, on his tombstone (Fig. 5). ${ }^{95}$

Croll's membership of the Royal Society and his friendship with Carey Foster was to prove fortuitous when his health was fading. Seven weeks before his death, Croll wrote to Foster: ${ }^{96}$

5 PITCULLEN CRESCENT, PERTH, 3rd November 1890.

MY DEAR FOSTER, - You will be sorry to hear of the condition of my health. A few months ago, just when I had about finished my new volume on The Philosophical Basis of Evolution, which will be issued shortly, my health suddenly gave way, and I am now so weak as to be able to do little more than move about the house.... What I am suffering from is a slow loss of power in the heart. This state of things will probably go on till the heart stops, an event which I am enabled to contemplate with the utmost composure, as it will be but the way of entrance to a better land.

There is one thing, however, which is weighing a little on my mind. I have no relations in Perth, or, indeed, almost anywhere. Mrs. Croll belongs to Forres, a small town about a hundred miles to the north, and I am anxious to see her settled there amongst her relations in the event of my

\footnotetext{
${ }^{90}$ Mentioned in the Statutes of the Royal Society dated 1847 and not changed until 1924, and '[i]f a Fellow fell into arrears their name would be publicly displayed in the Society meeting room until they paid up' (Virginia Mills, Royal Society, pers. comm. 8 July 2020).

${ }^{91}$ There seemed to be a large number of exemptions in the 17 th Century, including diplomats, scientific enthusiasts in the provinces and dons at Oxford, Cambridge and St Andrews (Hunter 1976, p. 50). By 1876, 'only Foreign Members (i.e. those who were not residents or citizens of the British Empire) and those elected from "the privileged classes" (i.e. Royalty and Privy Councillors) were exempt from paying the admission and annual subscription fees. So any Fellow resident in Britain, regardless of how far from London would pay the usual fees' (Virginia Mills, Royal Society, pers. comm. 8 July 2020).

${ }^{92}$ Barton (2003, p. 89) recorded how the mycologist Rev Miles Joseph Berkeley (1803-1889), a Royal Medallist (1863) of the Royal Society, did not gain election as FRS until 1879, the first year that new Fellows were not required to pay an entrance fee. Barton wondered if the expense involved had kept Berkeley from seeking election given his curacy of a poor parish and the need to care for his family of 15 children.

${ }^{93}$ British Library Loan 96 RLF 1/2220; Edwards \& Robinson (2021).

${ }^{94}$ Croll $(1887$, p. 41$)$.

${ }^{95}$ Irons (1896a, pp. 308, 488).

${ }^{96}$ Irons (1896a, pp. 482-83).
} 


\section{BX JAMES CROLL L.2.8 Z.K.S. \\ OF H.M. GEOLOGICAL SURVEX OF SCOTLAND}

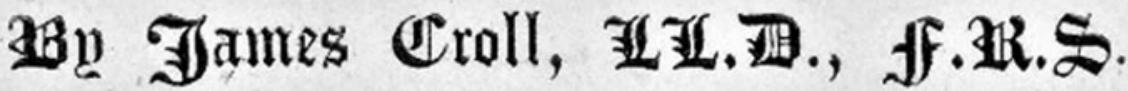

\section{CLIMATE AND TIME}

IN THEIR GEOLOGICAL RELATIONS :

\section{A THEORY OF SECULAR CHANGES OF THE EARTH'S CLIMATE.}

\section{By JAMES CROLL, LL.D., F.R.S., OF H.M. Geological Survey.}

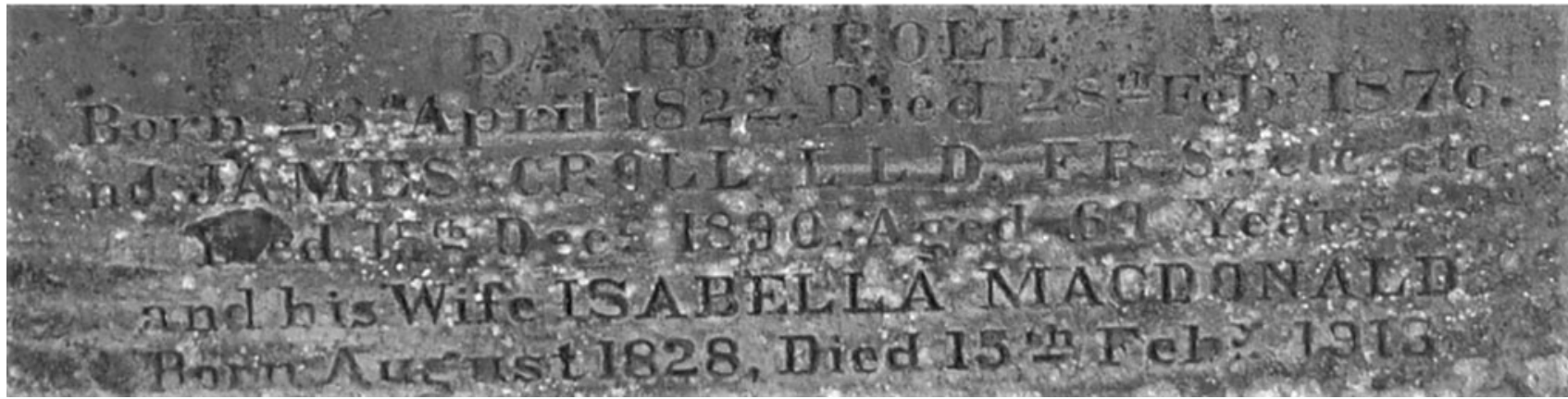

Figure 5 Post-nominals LL.D. and FRS: top, written into a copy of Climate and time (in the author's possession); centre, on a publicity leaflet (twice) for Climate and time; bottom, inscribed on James Croll's tombstone ('James Croll LL.D., F.R.S., etc. etc.') with the names of his brother David and wife Isabella also shown.

death. The expense of removal will be a considerable drain on her comparatively small means. Do you think that a sum, say $£ 50$ or so, might be obtained from the Royal Society Relief Fund for this purpose? You might kindly write and let me know your opinion on the matter.

I hope that Mrs. Foster, yourself, and family are keeping well. Apologising for troubling you, I am, yours most sincerely,
Foster had to confer with the Royal Society and was able to write to Mrs Croll a little over a week of her husband's death: ${ }^{97}$ 
LONDON, W., 23 December 1890.

DEAR MRS. CROLL, - This must be a mournful Christmas and New Year for you, now that you have lost the companion of so many years. I would not intrude upon you at such a time, but I should like to offer you the expression of my sincere sympathy, and to say how thoroughly I loved and respected your husband.

My chief business, however, in writing just now is to say that I had the satisfaction yesterday afternoon, at a meeting of the Scientific Relief Fund Committee, of voting a grant of $£ 100$ for your benefit. This sum is to be entrusted to Professor Geikie, ${ }^{98}$ at his request, and $£ 50$ is to be paid almost immediately, and the remainder in six months' time. I hope this assistance may be of service to you at this time, and that you will receive it as an indication of the honour in which Dr. Croll was held by scientific men in London. I only wish I had been able to announce the grant earlier, so that he might have known of it. - I am, dear Mrs. Croll, yours very truly,

\section{G. CAREY FOSTER}

This represented a piece of good news given Croll's failure to secure meaningful state funding in lieu of a full pension. ${ }^{99}$ James Campbell Irons recorded that all proceeds from the sales of the 'Autobiographical sketch' were to be handed to Isabella Croll. ${ }^{100}$

\section{The New York Academy of Sciences}

On 5 January 1876, following an application to the Supreme Court of the State of New York, the Lyceum of Natural History in the City of New York (founded in 1817) was authorised to change its corporate name to that of The New York Academy of Sciences. ${ }^{101}$ In that same year, James Croll was one of 23 new scientists elected to honorary membership of the Academy. This unusually large number of Honorary Members (Table 2) likely reflected a celebration of name change for the Academy or even a renewal - in its foundation year it had elected 28 Honorary Members, and a new honouree approximately every two years thereafter for the next six decades. Croll was already known to three of the new Members - his 'employer', the British geologist Archibald Geikie; Joseph Henry (1797-1878), electromagnetism pioneer and the first Secretary of the Smithsonian Institution; ${ }^{102}$ and William Carpenter, the British physiologist with whom he had a major academic dispute (see section 6 below). There is no doubting that Croll's cohort represented exalted scientific company.

In addition to these, Croll communicated with other honorary members of whom copies of letters existed. ${ }^{103}$ These correspondents lived in the USA (Alexander Agassiz (1835-1910), scientist and engineer, elected 1887; James Dwight Dana ${ }^{104}$ (1813-1895), geologist, elected 1852), in Britain (Charles Lyell, elected 1836; Roderick Impey Murchison, elected 1836; Charles Darwin, elected 1879; John Tyndall, elected 1887; James Geikie (1839-

\footnotetext{
${ }^{98}$ Archibald Geikie who is reminded in a letter from Herbert Rix, Assistant Secretary and Librarian of the Royal Society, dated 15 December 1893 , of his promise to produce an obituary notice for Croll, another for Andrew Ramsay, and to secure obituaries for several foreign fellows (NLB/8/737, Repository GB 117 The Royal Society).

${ }^{99}$ Edwards \& Robinson (2021).

${ }^{100}$ Irons (1896a, p. 4)

${ }^{101}$ NYAS (1909).

${ }^{102}$ Moyer (1997); Encyclopædia Britannica (2020). Croll sent a series of offprints (in this writer's possession) to Henry, dated 1870-1879, one of which (Croll 1875b) was inscribed to Henry.

${ }^{103}$ Irons (1896a).

${ }^{104}$ Also a Foreign Fellow of the Royal Societies of London and Edinburgh.
}

1915), elected 1901; Joseph Dalton Hooker (1817-1911), elected 1907) and elsewhere (e.g., the Norwegian Fridtjof Nansen (1861-1930), zoologist, polar explorer and Nobel Laureate, elected 1898).

One person who was unlikely to have nominated Croll was another autodidact, the Canadian-American astronomer and mathematician Simon Newcomb (1835-1909; elected 1891). Apart from famously declaring the impossibility of manned flight, ${ }^{105}$ and having a one-time interest in psychical research, ${ }^{106}$ he had been involved in the 'Croll-Newcomb controversy'107 consequent upon an adverse review of Croll's Climate and time. ${ }^{108}$

Much of the New York Academy of Science's archival material has been lost and nothing relating to Croll's nomination and acceptance has been found (Douglas Braaten, pers. comms. 25 May 2016, 29 January 2017). ${ }^{109}$

\section{Non-membership of the Royal Society of Edinburgh}

On the 13 February 1890, Mr James White, the honorary librarian of the Geological Society of Glasgow, read a paper on 'My ideas of "The Great Ice Age." The paper 'reviewed the whole subject of glacial action in its various aspects, strongly supporting the views expressed by Dr. James Croll, F.R.S.E., in his wellknown work, "Climate and Time". ${ }^{110}$ Except that Croll was never a Fellow of the Royal Society of Edinburgh. Nor does an archival search reveal any indication that James Croll had been nominated for the Fellowship. Examination of the minute books and other archives of the Society do not dissuade from the impression that Croll seemed not to have delivered a lecture or to have participated in any aspect of the life of Scotland's national academy. This is greatly surprising given Croll's presence in the Scottish capital and his prominence as a scientist and theoretician of international standing. Indeed, of his known work-based acquaintances ( $c f$. Fig. 6), Benjamin Neeve Peach (1842-1926), John Horne (1848-1928), Archibald Geikie and his brother James Geikie were FRSEs, while the Geikies' became Presidents of the Society (Table 3 ). ${ }^{111}$

The overlap in proposers for FRSE shown in Table 3 might be taken to reflect the shared educational backgrounds of members of the Society at this time - something that extended to the wider scientific community. ${ }^{112}$ In addition to Croll's office colleagues, six individuals who had supported his FRS nomination also had Royal Society of Edinburgh connections. He had also communicated with other Fellows, including mathematical physicist Peter Guthrie Tait (1831-1901), marine zoologist and oceanographer Charles Wyville Thomson (1830-1832) and botanist John Hutton Balfour (1808-1884), while chemist Alexander Crum Brown (1838-1922) was a signatory in the attempt to augment Croll's pension. ${ }^{113}$ By his own admission, Croll was something of a sociophobe ('I would rather be alone' ${ }^{, 14}$ ) and he most certainly eschewed stuffy academic meetings. Even if 'his shrinking

\footnotetext{
${ }^{105}$ Newcomb (1901).

${ }^{106}$ Moyer (1998).

${ }^{107}$ Irons (1896a, p. 520)

${ }^{108}$ Newcomb (1876); to which there were various rejoinders (e.g., McFarland 1876; Croll 1884).

${ }^{109}$ Wiley (2020)

${ }^{110}$ TGSG (1891, p. 236).

${ }^{111}$ Data from Waterston \& Macmillan Shearer (2006a, b) and other sources. Croll's biographer, James Campbell Irons, was also an FRSE, but for less than two years (1898-1900) - James Geikie was one of his supporters.

${ }^{112}$ Shapin (1974); Turner (1976); Porter (1978); Outram (1980); Fulford (2019).

${ }^{113}$ Irons (1896a).

${ }^{114}$ Irons (1896a, p. 18).
} 
Table 2 Honorary members of the New York Academy of Sciences elected to the Academy in 1876.

\begin{tabular}{|c|c|c|c|}
\hline Name $^{1}$ & Location & Occupation & Nationality $^{2}$ \\
\hline R. Ackermann & Stockholm & & Swedish? \\
\hline William Boyd Dawkins & Manchester & Geologist, archaeologist & British \\
\hline Robert Bunsen & Heidelberg & Chemist & German \\
\hline William P. [B.?] Carpenter & London & Physiologist & British \\
\hline James Croll & Edinburgh & Geologist & British \\
\hline John William Dawson & Montreal & Geologist & Canadian \\
\hline Alfred Louis Olivier Legrand Des Cloizeaux & Paris & Mineralogist, photographer & French \\
\hline Henri Étienne Sainte-Claire Deville & Paris & Chemist & French \\
\hline Jean Baptiste André Dumas & Paris & Chemist & French \\
\hline Philip Grey Egerton & England & Geologist & British \\
\hline Archibald Geikie & Haslemere & Geologist & British \\
\hline Hanns Bruno Geinitz & Dresden & Geologist & German \\
\hline Emmanuel-Louis Gruner & Paris & Engineer, geologist & French \\
\hline Oswald Heer & Zürich & Geologist & Swiss \\
\hline Joseph Henry & Washington, D.C. & Physicist & American \\
\hline Viktor von Lang & Vienna & Chemist & Austrian \\
\hline James Clerk Maxwell & Cambridge & Physicist & British \\
\hline Hieronymous Theodor Richter & Freiburg & Chemist & German \\
\hline Pietro Angelo Secchi & Rome & Astronomer & Italian \\
\hline P. Ritter von Turner & Seoben & & \\
\hline Friedrich Wöhler & Göttingen & Chemist & German \\
\hline Charles Adolphe Wurtz & Paris & Chemist & French \\
\hline
\end{tabular}

Note: where known, the occupations are listed. In 1902, the disciplinary sections of the Academy were Astronomy, Physics and Chemistry, Biology, Geology and Mineralogy, and Anthropology and Psychology. Source: NYAS 1909.

${ }^{1} \mathrm{~A}$ number of the names listed appear to be misspelt or incomplete in the original list. Where there is a high probability of identity, they have been corrected here. ${ }^{2}$ Present day.

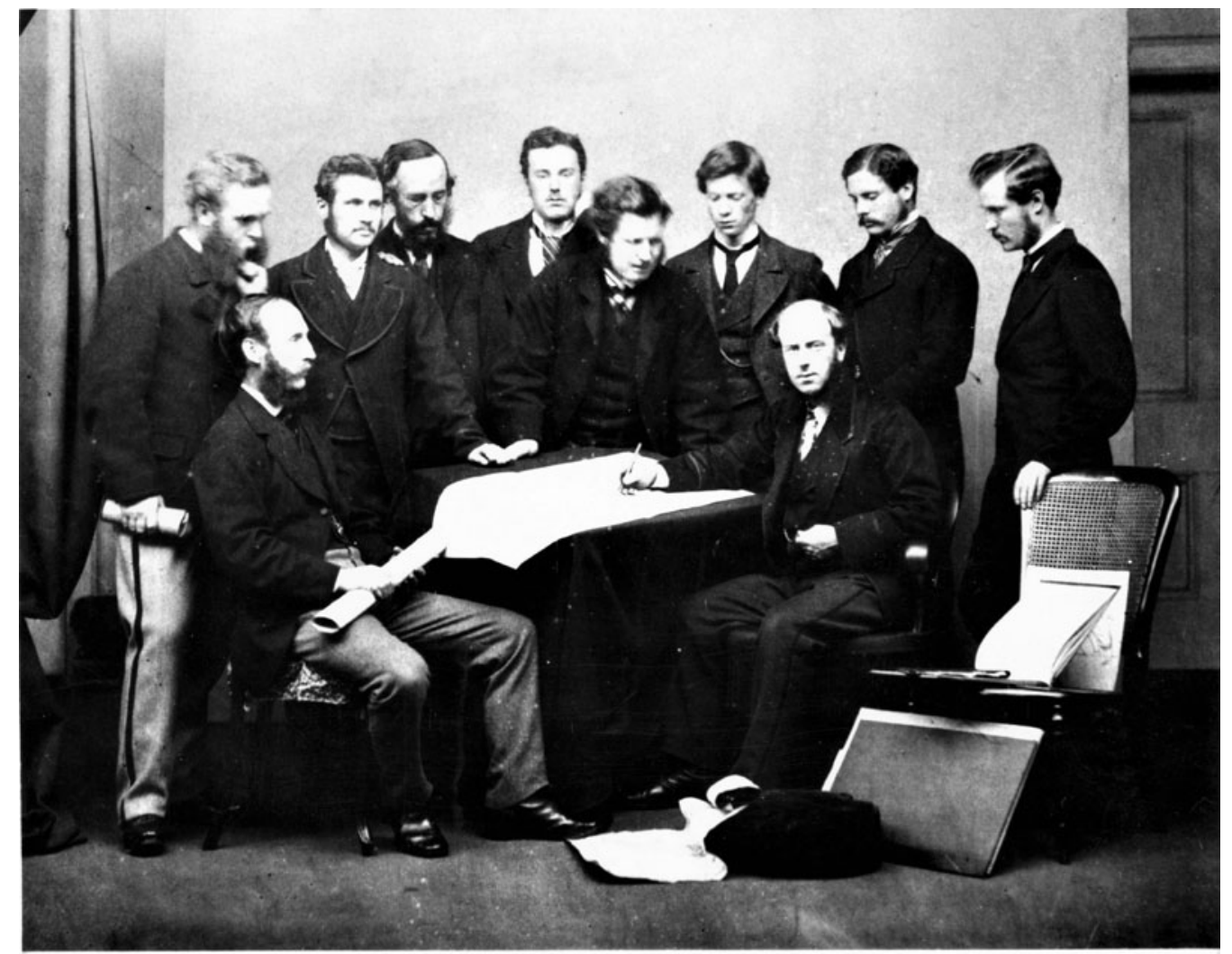

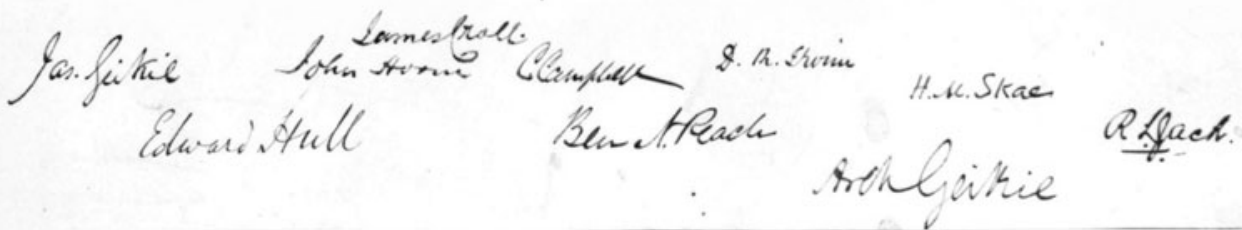

Figure 6 Picture of James Croll with other employees of the Geological Survey in Edinburgh, 1868. Standing left to right: James Geikie, John Horne, James Croll, C. R. Campbell, Ben Peach, Duncan Robertson Irvine, Harriman Malcolm Skae and Robert Logan Jack. Seated: Edward Hull and Archibald Geikie (permit number CP20/060, photo P008752 courtesy of the British Geological Survey Source: http://earthwise.bgs.ac.uk/index.php/File: P008752.jpg). 
modesty led him to decline' requests, ${ }^{115}$ he nevertheless maintained a respectable level of correspondence with other scientists.

It seems inconceivable that Croll would not have been asked to become an FRSE, and that he likely declined or did not seek nomination. It might be reasonable to surmise that Croll regarded Fellowship of the Royal Society of London as a superior accolade to that of Edinburgh. He had sought admission to the former and, as discussed above, he used the post-nominal FRS as a matter of course. As Irons remarked, ${ }^{116}$ '[i]n 1876 he was elected a Fellow of the Royal Society of London, one of the highest honours attainable by a man of science, and which was highly appreciated. ${ }^{117}$ Perhaps this negated any desire to be a Fellow of both and the costs of two memberships might have seemed unreasonable given his annual salary (upon retirement) of $£ 350$. $^{118}$

\section{Discussion}

The year 1876 had not started well for Croll - '[i]n February 1876, my brother, who had been staying with us ever since my mother's death, died suddenly from heart disease'. ${ }^{119}$ This was the same brother, David (53 years of age), who had performed many of Croll's janitorial tasks at the Andersonian Institute, allowing Croll 'a great deal of time for study'. ${ }^{120}$ In the Sketch, having recounted the demise of his brother, Croll immediately goes on to list the achievements relating to that same year, as well as others occurring shortly before and afterwards: ${ }^{121}$

I was afterwards chosen an Honorary Member of the Bristol Natural Society, of the Psychological Society of Great Britain, of the Glasgow Geological Society, of the Literary and Antiquarian Society of Perth, and of the Perthshire Society of Natural Science. I had the honour of receiving from the Geological Society of London the balance of the proceeds of the Wollaston Donation Fund in 1872, the Murchison Fund in 1876, and the Barlow-Jamieson Fund in 1884.

It seems likely that 1876 was regarded by Croll as the apogee of his scientific life. His papers and the book Climate and time had enabled him to attain 'a well-recognised place among men of science', ${ }^{122}$ while the honorary doctorate and the Fellowship of the Royal Society of London were distinctions which brought him the tangible demonstration of that recognition.

There are other related components of his life and some of these are reflected upon in the following.

\subsection{Origins and patronage}

Andrew Ramsay's suspicion that James Croll was 'almost quite selfeducated' was notably apposite and, in the context of 1876, the accolades showered upon Croll were impressive. His efforts and genius enabled him to achieve more than many scientists with conventionally advantageous beginnings. It is important to stress, though, that Croll's achievements were not unique for an autodidact. There were numerous other self-taught and lauded contemporaries, including Thomas Henry Huxley, Alfred Russel Wallace and Simon Newcomb, although the first two of these were born

\footnotetext{
${ }^{115}$ Irons (1896a, p. 250)

${ }^{116}$ Irons (1896a, p. 309).

${ }^{117}$ Three quarters of a century earlier, the Royal Society of Edinburgh 'was arguably the second-ranking scientific society in Britain' (Shapin 1974, p. 2).

${ }^{118}$ In Irons (1896a, pp. 374-75) it is stated that his pension was ' $£ 75,16$ s. $8 \mathrm{~d}$., a sum equal merely to thirteen sixtieths of his annual salary... a beggarly allowance'. This indicates an annual salary upon retirement of $£ 350$, or $£ 31,840-£ 35,100$ at today's values (see footnote 62 ).

${ }^{119}$ Croll $(1887$, p. 38$)$

${ }^{120}$ Croll $(1887$, p. 31$)$

${ }^{121}$ Croll (1887, p. 38); Edwards \& Robinson (2021).

${ }^{122}$ Irons (1896a, p. 267)
} 
into financially distressed, middle-class families. Likewise, others were of humble origin, of whom Michael Faraday, George Boole, John Tyndall and John Cairns may be cited. In addition, Croll's accomplishments were realised in a period when many gifted laypersons made less distinguished, though valuable, contributions. ${ }^{123}$

It cannot be denied that Croll enjoyed a degree of recognition leading to later patronage with respect to his scientific endeavours. Andrew Ramsay saw sufficient promise in Croll's early geological papers to commend him to David Forbes; Archibald Geikie spotted his potential and headhunted him (twice) for a post with the Geological Survey of Scotland and sought to ensure that the Civil Service examination did not prove an impediment to his progress; ${ }^{124}$ and Matthew Forster Heddle (twice) recommended Croll for the honorary degree of Doctor of Laws. Charles Darwin, John Tyndall, William Thomson and others supported him for Fellowship of the Royal Society of London. George Carey Foster, known by Croll since his days at the Andersonian Institute, was praised by James Campbell Irons as 'a faithful [friend]...down to the date of Croll's death' without whose assistance 'he would not have been able to overtake nearly so much work as he did'. ${ }^{125}$ It is regrettable that lacunae in the archival resources of the New York Academy of Sciences do not permit a glimpse of Croll's supporter(s) there, but Joseph Henry of the Smithsonian seems a possible candidate.

\subsection{A 'singularly modest man'}

Andrew Ramsay's recognition of James Croll's modesty in his letter of 26 May 1865 was particularly perceptive. The blend of ability and modesty in Croll was well attested and they may both have contributed to the rewards which came his way. Irons' text is replete with illustrations: 'there always seemed something so modest and unaffected about him which naturally

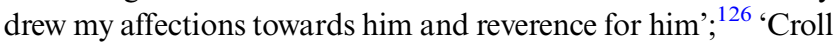
had, to the day of his death, a modest, shy, dry, and almost speechless manner, except on occasions when he was drawn out by congenial conversation among real friends'; ${ }^{127}$

I was much struck with the simple modesty of one of so grand attainments... Though a giant in intellect, and an authority on all the subjects he studied, he had the simplest, most modest, and unaffected manner, and would talk pleasantly to a little child, to the most illiterate or the most intellectual man with equal apparent interest, earnestness, and serenity. ${ }^{128}$

In a letter to the American geologist Alexander Winchell (1824 1891), ${ }^{129}$ Croll felt impelled to note self-deprecatingly: ${ }^{130}$

By the way, you style me in the book a professor. ${ }^{131} \mathrm{I}$ am only a plain, self-educated man; and although I was a good few years on the Geological Survey, yet I know but very little about geology proper, my studies being principally in physics and philosophy.

None of this inhibited a willingness to engage in vigorous argument however $-{ }^{\prime}[\mathrm{t}]$ hough one of the most modest of men,

\footnotetext{
${ }^{123}$ Goldstein (1994); Secord (1994, 2003); Vetter (2011).

${ }^{124}$ Edwards \& Robinson (2021).

${ }^{125}$ Irons (1896a, p. 259)

${ }^{126}$ Irons $(1896 a$, p. 65$)$.

${ }^{127}$ Irons (1896a, p.70).

${ }^{128}$ Irons (1896a, pp. 368-69).

${ }^{129}$ Variously professor of geology at Ann Arbor, University of Michigan and Vanderbilt University, cotton planter, state geologist for Michigan and first Chancellor of Syracuse University (Syracuse University 2020). He was forced to leave Vanderbilt University because of his religious rather than his racist views (Scott 2018).

${ }^{130}$ Irons (1896a, p. 451)

${ }^{131}$ Winchell (1863, p. 374).
}

Croll was a keen controversialist ${ }^{132}$ - and allusion has already been made to the debates with Carpenter and Newcomb.

\subsection{Sociability and learned societies}

The accolades bestowed upon Croll were based upon published work. His aversion to attending the meetings of learned societies and to deliver lectures ${ }^{133}$ seemed not to lessen the esteem in which he was held, though it may have been a factor in his apparent lack of engagement with the Royal Society of Edinburgh. Croll declined opportunities to attend meetings of the British Association for the Advancement of Science (in Edinburgh in 1871, Brighton 1872 and Glasgow in 1876), partly citing health issues. ${ }^{134}$ It is possible that the threat of public conflict with William Carpenter may have played a part in the decision not to go to Brighton. It might be added that his frequent debilitating head pain discouraged 'going out to public meetings or to dinner or evening parties' during his 13 years in Edinburgh, when he recalled 'being only twice at a scientific meeting, and once at a concert'. ${ }^{135}$ On 17 August 1876, he wrote candidly to his friend the Rev Dr James Morison (1816-1893) that ' $[t]$ he real truth is, there is a cold materialistic atmosphere around scientific men in general, that I don't like. I mix but little with them. ${ }^{136}$

\subsection{Finale}

\section{His letter to Morison (above) had continued:}

There is, however, indication of a reaction beginning to take place towards something more spiritual in science; and the day, it is to be hoped, is not far distant when religion, philosophy, and science will go hand in hand.

While 1876 did not represent a denouement for Croll the scientist - after all, he went on to publish more than 20 further papers and the book Discussions on climate and cosmology, ${ }^{137}$ - he clearly had his mind on 'work of a more important character', ${ }^{138}$ as declared in the preface to his 'Autobiographical sketch'. He was here referring to production of his book The philosophical basis of evolution, ${ }^{139}$ which appeared the month before his death. His final transition to philosopher of religion was not, on the face of it, a complete abandonment of science, as his final book has 'main conclusions...deduced from facts or from fundamental principles' ${ }^{140}$ and its chapter headings contain such terms as force, molecular motion, causation, natural selection and determination. Reaction to this work of theological determinism varied from the hagiographic ('the argument...is simply irresistible"141) to the hostile ('perilously near the absurd" ${ }^{142}$ ).

'Ending on this metaphysical and religious note is not in harmony with how Croll is usually remembered', ${ }^{143}$ but it does reflect Croll's perception of life and the essence of the man. He himself considered that his paper 'Evolution by force impossible: a new argument against materialism' ${ }^{144}$ was 'by far the best thing I have ever written' (letter to the Rev Osmond Fisher, 4 February 1882). ${ }^{145}$ Nevertheless, in spite of this strong undercurrent of

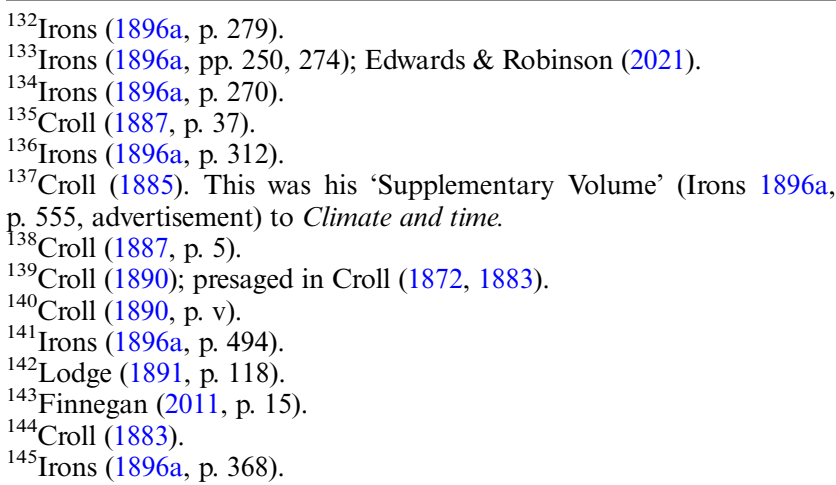


metaphysics, it was physical science that brought him widespread admiration and respect, and none more so than became evident in the year 1876 .

\section{Supplementary material}

Supplementary material is available online at https://doi.org/10. 1017/S1755691021000074.

\section{Acknowledgements}

I am very appreciative for the provision of information, and permission to publish, from a number of individuals and institutions: Rachel Hart, Keeper of Manuscripts and Muniments and Deputy Head of Special Collections, University of St Andrews; Vicky Hammond, formerly Journals and Archives Officer, Royal Society of Edinburgh; Virginia Mills, Archivist and Katherine Marshall, Picture Curator, Royal Society of London; Douglas Braaten, Chief Scientific Officer and Ellis Rubinstein, President Emeritus, New York Academy of Sciences; Sally Boardman, Intellectual Property Rights, British Geological Survey; Fabienne Michaud, Head of Library and Information Services, the Geological Society of London. Laura Brassington, Department of History and Philosophy of Science, University of Cambridge, and two anonymous referees are thanked for their constructive comments on the manuscript.

\section{References}

Abbott, E. \& Campbell, L. 1897. The life and letters of Benjamin Jowett, MA, Master of Balliol College, Oxford. London: Murray.

A. G. 1890. James Croll, F.R.S. Nature 43, 180-81.

Anon. [= Croll, J.] 1857. Philosophy of theism: an inquiry into the dependence of theism on metaphysics. London: Ward \& $\mathrm{Co}$

Anon. 1886. Captain sir Frederick J. O. Evans, R.N., K.C.B., F.R.S. Monthly Notices of the Royal Astronomical Society 46, 183-87.

Barton, R. 2003. 'Men of science': language, identity and professionalization in the mid-Victorian scientific community. History of Science 41, 73-119.

Bayne, T. W. 1901. Cairns, John. In Lee, S. (ed.) Dictionary of national biography, 1901 Supplement, 369-71. London: Smith, Elder \& Co.

Bol'shakov, V. A., Kapitsa, A. P. \& Rees, W. G. 2012. James Croll: a scientist ahead of his time. Polar Record 48, 201-05.

Briggs, W. W. 2020. North American Scholar. Whitney, William Dwight. Rutgers School of Arts and Sciences. Database of Classical Scholars. https://dbcs.rutgers.edu/all-scholars/9227-whitney-williamdwight (accessed June 2020).

Bryson, B. 2004. A short history of nearly everything. London: Black Swan.

Burkhardt, F. \& Smith, S. (eds) 1994. A calendar of the correspondence of Charles Darwin, 1821-1882, with supplement. Cambridge: Cambridge University Press.

Campbell, L. \& Garnett, W. 1882. The life of James Clerk Maxwell: with a selection from his correspondence and occasional writings and a sketch of his contributions to science. London: Macmillan.

Clerke, A. M. (revised by David Gavine) 2010. Grant, Robert (1814 1892). Oxford dictionary of national biography. https://doi.org/10. 1093/ref:odnb/11285 (accessed June 2020).

Craik, E. M. 2004. Campbell, Lewis (1830-1908). Oxford dictionary of national biography. https://doi.org/10.1093/ref:odnb/32270 (accessed June 2020).

Croll, J. 1861. XXXVIII. Remarks on Ampère's experiment on the repulsion of a rectilinear electrical current on itself. The London, Edinburgh, and Dublin Philosophical Magazine and Journal of Science 21, 247-50.

Croll, J. 1862a. LII. Remarks on Ampère's experiment on the repulsion of a rectilinear electrical current on itself: to the editors of the Philosophical Magazine and Journal. The London, Edinburgh, and Dublin Philosophical Magazine and Journal of Science 23, 365-67.

Croll, J. 1862b. Ampèrian repulsion. The London, Edinburgh, and Dublin Philosophical Magazine and Journal of Science 24, 326.

Croll, J. 1864. XIII. On the physical cause of the change of climate during geological epochs. The London, Edinburgh, and Dublin Philosophical Magazine and Journal of Science 28, 121-37.
Croll, J. 1867a. On the change in obliquity of the ecliptic; its influence on the climate of the polar regions and level of the sea. Transactions of the Geological Society of Glasgow 2, 177-98.

Croll, J. 1867b. On the excentricity of the Earth's orbit and its relations to the glacial epoch. The London, Edinburgh, and Dublin Philosophical Magazine and Journal of Science 33, 1-13.

Croll, J. 1872. I. What determines molecular motion?-The fundamental problem of nature. The London, Edinburgh, and Dublin Philosophical Magazine and Journal of Science 44, 1-25.

Croll, J. 1875a. Climate and time in their geological relations: a theory of secular changes of the earth's climate. London: Daldy, Isbister \& Co.

Croll, J. 1875b. XXVI. The 'Challenger's' crucial test of the wind and gravitation theories of oceanic circulation. The London, Edinburgh, and Dublin Philosophical Magazine and Journal of Science 50, 242-50.

Croll, J. 1883. ART. II. - Evolution by force impossible: a new argument against materialism. The British Quarterly Review 77, 35-71.

Croll, J. 1884. XXXII. Remarks on professor Newcomb's "Rejoinder". The London, Edinburgh, and Dublin Philosophical Magazine and Journal of Science 17, 275-81.

Croll, J. 1885. Discussions on climate and cosmology. London: Edward Stanford.

Croll, J. 1887 (published 1896). Autobiographical sketch of James Croll. In Irons J. C. (ed.) Autobiographical sketch of James Croll LL.D., F.R.S., etc. with memoir of his life and work, 9-41, Prefatory note, 5. London: Edward Stanford.

Croll, J. 1890. The philosophical basis of evolution. London: Edward Stanford.

Darwin. 2020. Darwin correspondence project. University of Cambridge. https://www.darwinproject.ac.uk/ (accessed June 2020).

den Otter, S. M. 2012. Wallace, William (1843-1897). Oxford Dictionary of National Biography. Oxford University Press. https://doi.org/10. 1093/ref:odnb/28546 (accessed June 1920).

Dry, S. 2019. Waters of the world: the story of the scientists who unravelled the mysteries of our seas, glaciers, and atmosphere - and made the planet whole. London: Scribe.

Edwards, K. J. \& Robinson, M. 2021. James Croll - a man 'greater far than his work'. For submission to Earth and Environmental Science Transactions of the Royal Society of Edinburgh 112, 173-192.

Encyclopædia Britannica. 2020. Joseph Henry, American physicist. https:// www.britannica.com/biography/Joseph-Henry (accessed July 2020).

F. R. S. 1874. Ocean circulation - Dr. Carpenter and Mr. Croll. Nature 10, 83-84.

Farrow, G. E. 2001. James Croll: a $19^{\text {th }}$ century pioneer of climate change. Glasgow Naturalist 23, 9-18.

Ferrier, J. F. 1854. Institutes of metaphysic: the theory of knowing and being. Edinburgh: W. Blackwood.

Finnegan, D. A. 2011. James Croll, metaphysical geologist. Notes and Records of the Royal Society 66, 69-88.

Fison, A. H. 1919. Obituary notice, George Carey Foster. Journal of the Chemical Society, Transactions 115, 412-27.

Fleming, J. R. 2006. James Croll in context: the encounter between climate dynamics and geology in the second half of the nineteenth century. History of Meteorology 3, 43-53.

Forbes, J. D. 1861. XII. Note respecting Ampère's experiment on the repulsion of a rectilinear electrical current on itself. The London, Edinburgh, and Dublin Philosophical Magazine and Journal of Science 21, 81-86.

Fulford, T. 2019. The role of patronage in early nineteenth-century science, as evidenced in letters from Humphry Davy to Joseph Banks. Notes and Records of the Royal Society of London 73, 457-75.

Geikie, A. 1895. Memoir of Sir Andrew Crosbie Ramsay. London: Macmillan \& Co.

Geological Society. 2020. Past presidents. https://www.geolsoc.org.uk/ About/History/Past-Presidents (accessed June 2020).

Goldstein, D. 1994. "Yours for Science": the Smithsonian Institution's correspondents and the shape of scientific community in nineteenthcentury America. Isis 85, 573-99.

Gribbin, J. R. \& Gribbin, M. 2001. Ice age. London: Allan Lane.

Harrison, W. J. 1885-1900. Evans, Frederick John Owen (DNB00). In Stephen, L. (ed.) Dictionary of national biography, 18, 61-62. London: Smith, Elder \& Co

Hays, J. D., Imbrie, J. \& Shackleton, N. J. 1976. Variations in the Earth's orbit: pacemaker of the ice ages. Science (New York, N.Y.) 194, 1121-31.

Herries Davies, G. L. 2004. Hull, Edward (1829-1917) Oxford dictionary of national biography. https://doi.org/10.1093/ref:odnb/53969 (accessed June 2020).

Horne, J. 1892. Obituary notice of Dr James Croll, F.R.S. Transactions of the Edinburgh Geological Society 6, 171-87.

Hull, E. 1910. Reminiscences of a strenuous life. London: Hugh Rees.

Hunter, M. 1976. The social basis and changing fortunes of an early scientific institution: an analysis of the membership of the Royal Society, 
1660-1685. Notes and Records of the Royal Society of London 31, 9-114.

Imbrie, J. \& Imbrie, K. P. 1979. Ice ages: solving the mystery. London: Macmillan

Irons, J. C. 1896a. Autobiographical sketch of James Croll LL.D., F.R.S. etc. with memoir of his life and work. London: Edward Stanford.

Irons, J. C. 1896b. Appendix. List of scientific papers and works. In Irons, J. C. (ed.) Autobiographical sketch of James Croll LL.D., F.R.S., etc. with memoir of his life and work, 527-35. London: Edward Stanford.

Johnston, H. H. 2015. Matthew Forster Heddle: mineralogist and mountaineer. Edinburgh: National Museums Scotland.

Keefe, J. 2015. James Frederick Ferrier: the return of idealism and the rejection of common sense. In Graham, G. (ed.) Scottish philosophy in the nineteenth and twentieth centuries, 67-94. Oxford: Oxford University Press.

Kushner, D. 2004. Croll, James (1821-1890), Oxford dictionary of national biography. https://doi.org/10.1093/ref:odnb/6744 (accessed June 2020).

Lodge, O. 1891. The philosophical basis of evolution. Academy 40, 117-19.

Lyons, H. G. 1938. The growth of the Fellowship. Notes and Records of the Royal Society of London 1, 40-48.

Lyons, H. G. 1939. The composition of the fellowship and the council of the society. Notes and Records of the Royal Society of London 2, 108-26.

McFarland, R. W. 1876. Curve of eccentricity of the Earth's orbit. American Journal of Science 66, 456-58.

McGilvary, E. B. 1900. Book review. Lectures and essays on natural theology and ethics by William Wallace and Edward Caird. The Philosophical Review 9, 188-93.

Moyer, A. E. 1997. Joseph Henry. Washington, DC: Smithsonian Institution Press.

Moyer, A. E. 1998. Simon Newcomb: astronomer with an attitude. Scientific American 279, 88-93.

Newbigin, M. I. \& Flett, J. S. 1917. James Geikie. The man and the geologist. Edinburgh: Oliver and Boyd.

Newcomb, S. 1876. Review of Croll's climate and time with especial reference to the physical theories of climate maintained therein. American Journal of Science 64, 263-73.

Newcomb, S. 1901. Is the airship coming? Mc Clure's Magazine 17, 432-35.

NYAS. 1909. The organization of the New York Academy of Sciences. Annals of the New York Academy of Sciences 19, 357-85.

O. J. L. 1920. George Carey Foster, 1835-1919. Proceedings of the Royal Society of London, Series A 96, xvii-xviii.

OED. 2014. Epistemology. Oxford English dictionary. 3rd edn. Oxford: Oxford University Press.

Oldroyd, D. 2004. Geikie, sir Archibild (1835-1924). Oxford dictionary of national biography. https://doi.org/10.1093/ref:odnb/33364 (accessed June 2020)

Outram, D. 1980. Politics and vocation: French science, 1793-1830. British Journal for the History of Science 13, 27-43.

Piskorska, A. 2016. Humour and the popular stereotypes of Scots. In Korzeniowska, A. \& Szymańska, I. (eds) Scottish culture: dialogue and self-expression, 369-79. Warsaw: Wydawnictwo Naukowe Semper

Porter, R. 1978. Gentlemen and geology: the emergence of a scientific career, 1660-1920. The Historical Journal 21, 809-36.

Reid, J. S. 2008. James Clerk Maxwell's Scottish chair. Philosophical Transactions of the Royal Society A: Mathematical, Physical and Engineering Sciences 366, 1661-84.

Robinson, M. 2020. Inspiring people at home: Mike Robinson RSGS CEO. https://www.youtube.com/watch?time_continue=10\&v=FKF8novHwiU\&feature=emb_logo (accessed June 2020).

Scott, M. 2018. Alexander Winchell. http://www.strangescience.net/ winchell.htm (accessed July 2020).

Secord, A. 1994. Science in the pub: artisan botanists in early nineteenth century Lancashire. History of Science 32, 269-315.
Secord, A. 2003. "Be what you would seem to be": Samuel Smiles, Thomas Edward, and the making of a working-class scientific hero. Science in Context 16, 147-73.

Secord, J. A. 1986. The Geological Survey of Great Britain as a research school, 1839-1855. History of Science 24, 223-75.

Secord, J. A. 2000. Victorian sensation: the extraordinary publication, reception, and secret authorship of Vestiges of the Natural History of Creation. Chicago: University of Chicago Press.

Shapin, S. 1974. Property, patronage, and the politics of science: the founding of the Royal Society of Edinburgh. The British Journal for the History of Science 7, 1-41.

Smith, R. 2006. Carpenter, William Benjamin (1813-1885). Oxford dictionary of national biography. https://doi.org/10.1093/ref:odnb/4742 (accessed August 2020).

STRT862J. 2020. Stuart, James. A Cambridge alumnus database. University of Cambridge. http://venn.lib.cam.ac.uk/cgi-bin/search2018. pl? sur $=\&$ suro $=w \&$ fir $=\&$ firo $=c \& c i t=\&$ cito $=c \& c=a l l \& z=a l l \&-$ tex $=$ STRT $862 \mathrm{~J} \&$ sye $=\&$ eye $=\& \mathrm{col}=$ all $\&$ maxcount $=50$ (accessed June 2020).

Sugden, D. E. 2014. James Croll (1821-1890): ice, ice ages and the Antarctic connection. Antarctic Science 26, 604-13.

Sykes, A. H. 2004. Sharpey, William (1802-1880). Oxford dictionary of national biography. https://doi.org/10.1093/ref:odnb/25238 (accessed July 2020).

Syracuse University. 2020. Alexander Winchell papers. https://web.archive. org/web/20140116095254/http://archives.syr.edu/collections/chancellors/sua_winchell_a.htm (accessed July 2020).

Tasch, P. 1986. James Croll and Charles Lyell as glacial epoch theorists. Earth Sciences History 5, 131-33.

TGSG. 1891. Proceedings for session 1889-90. Transactions of the Geological Society of Glasgow 9, 233-40.

The Times. 1897. Obituary - professor William Wallace. The Times 20 February, 12.

Thompson, R. 2015. Roy Thompson on James Croll. https://www.youtube.com/watch?v=vmTcSFglWaM (accessed June 2020).

Thomson, W. 1891. November 30, 1891. Anniversary meeting. Proceedings of the Royal Society of London 50, 218-46.

Turner, F. M. 1978. The Victorian conflict between science and religion: a professional dimension. Isis 69, 356-76.

Turner, G. L.'E. (ed.) 1976. The patronage of science in the nineteenth century. Leiden: Noordhoff International.

University of Strathclyde. 2020. Anderson's college, Glasgow. https:// atom.lib.strath.ac.uk/andersons-college-glasgow (accessed September 2020).

Vanity Fair. 1899. Statesmen. Dr James Stuart, M.P. Vanity Fair 5 October $1899,715$.

Vetter, J. 2011. Introduction: lay participation in the history of scientific observation. Science in Context 24, 127-41.

Wallace, W. 1898. In Caird E. (ed.) Lectures and essays on natural theology and ethics. Oxford: Clarendon Press.

Waterston, C. D. \& Macmillan Shearer, A. 2006a. Biographical index of former Fellows of the Royal Society of Edinburgh 1783-2002, Part I, A-J. https://www.rse.org.uk/cms/files/fellows/biographical_index/ fells_indexp1.pdf

Waterston, C. D \& Macmillan Shearer, A. 2006b. Biographical index of former Fellows of the Royal Society of Edinburgh 1783-2002, Part I, A-J., Part II, K-Z. https://www.rse.org.uk/cms/files/fellows/biographical index/fells indexp2.pdf

Wiley. 2020. Wiley digital archives. The New York Academy of Sciences. https://www.wileydigitalarchives.com/the-new-york-academy-of-sciences/ (accessed July 2020).

Winchell, A. 1863. World-life or comparative geology. Chicago: S.C. Griggs and Company.

Wunsch, C. \& Ferrari, R. 2018. 100 years of the ocean general circulation. Meteorological Monographs 59, 7.1-7.32.

MS received 30 October 2020. Accepted for publication 1 February 2021. First published online 24 May 2021 